Check for updates

Cite this: RSC Adv., 2020, 10, 41883

Received 11th August 2020

Accepted 6th November 2020

DOI: $10.1039 /$ dOra06919a

rsc.li/rsc-advances

\title{
SiC mesoporous membranes for sulfuric acid decomposition at high temperatures in the iodine- sulfur process $\dagger$
}

\author{
Xin Yu, (D) Qing Wang, (D) Hiroki Nagasawa, (D) Masakoto Kanezashi (D) \\ and Toshinori Tsuru iD *
}

Inorganic microporous materials have shown promise for the fabrication of membranes with chemical stability and resistance to high temperatures. Silicon-carbide ( $\mathrm{SiC}$ ) has been widely studied due to its outstanding mechanical stability under high temperatures and its resistance to corrosion and oxidation. This study is the first to prepare mesoporous SiC membranes for use in sulphuric acid decomposition to achieve thermochemical water splitting in the iodine-sulfur process. Single-gas permeation was carried out to confirm the stability of this mesoporous membrane under exposure to steam and $\mathrm{H}_{2} \mathrm{SO}_{4}$ vapor. Benefiting from the excellent chemical stability of the $\alpha-\mathrm{Al}_{2} \mathrm{O}_{3}$ membrane support and the SiC particle layer, the $\mathrm{SiC}$ membrane exhibited stable gas permeance without significant degradation under $\mathrm{H}_{2} \mathrm{SO}_{4}$ vapor treatment at $600{ }^{\circ} \mathrm{C}$. Additionally, with extraction, the membrane reactor exhibited an increased conversion from 25 to $41 \%$ for $\mathrm{H}_{2} \mathrm{SO}_{4}$ decomposition at $600{ }^{\circ} \mathrm{C}$. The high performance combined with outstanding stability under acidic conditions suggests the developed $\mathrm{SiC}$ membrane is a promising candidate for $\mathrm{H}_{2} \mathrm{SO}_{4}$ decomposition in a catalytic membrane reactor.
\end{abstract}

\section{Introduction}

Over the past twenty years, the water-splitting iodine-sulfur (IS) process has been extensively investigated as a sustainable technology with a net production of $\mathrm{H}_{2}$ and $\mathrm{O}_{2}$, at much lower temperatures compared with the direct thermal decomposition of water. ${ }^{1-6}$ The IS process involves cyclic reactions such as the Bunsen reaction and the thermal decompositions of sulfuric acid at $850-950{ }^{\circ} \mathrm{C}$ and hydroiodic acid at $450{ }^{\circ} \mathrm{C}$. In these cycles, the decomposition of sulfuric acid requires temperatures so high that the heat of solar or nuclear energy must be utilized. ${ }^{3,5-7}$

Net reaction:

$$
2 \mathrm{H}_{2} \mathrm{O} \leftrightarrow 2 \mathrm{H}_{2}+\mathrm{O}_{2} \text { (water-splitting) }
$$

Bunsen reaction:

$$
2 \mathrm{H}_{2} \mathrm{O}+\mathrm{I}_{2}+\mathrm{SO}_{2} \leftrightarrow 2 \mathrm{HI}+\mathrm{H}_{2} \mathrm{SO}_{4}\left(\sim 120^{\circ} \mathrm{C}\right)
$$

$\mathrm{H}_{2}$ production:

Department of Chemical Engineering, Graduate School of Engineering, Hiroshima University, 1-4-1 Kagamiyama, Higashi-Hiroshima 739-8527, Japan.E-mail: tsuru@ hiroshima-u.ac.jp

$\dagger$ Electronic supplementary information (ESI) available. See DOI: 10.1039/d0ra06919a

$$
2 \mathrm{HI} \leftrightarrow \mathrm{I}_{2}+\mathrm{H}_{2}\left(350-450{ }^{\circ} \mathrm{C}\right)
$$

$\mathrm{O}_{2}$ production:

$$
\begin{aligned}
& \mathrm{H}_{2} \mathrm{SO}_{4} \leftrightarrow \mathrm{H}_{2} \mathrm{O}+\mathrm{SO}_{3}\left(T>300^{\circ} \mathrm{C}\right) \\
& \mathrm{SO}_{3} \leftrightarrow \mathrm{SO}_{2}+0.5 \mathrm{O}_{2}\left(\sim 850-950{ }^{\circ} \mathrm{C}\right)
\end{aligned}
$$

$\mathrm{H}_{2} \mathrm{SO}_{4}$ decomposes to produce $\mathrm{O}_{2}$ in the following two steps: $\mathrm{H}_{2} \mathrm{SO}_{4}$ dissociates into $\mathrm{H}_{2} \mathrm{O}$ at $300{ }^{\circ} \mathrm{C}$ (eqn (3)) and sulfur trioxide $\left(\mathrm{SO}_{3}\right)$, which further decomposes into sulfur dioxide $\left(\mathrm{SO}_{2}\right)$ and oxygen (eqn (4)) via catalysis around 850 to $950{ }^{\circ} \mathrm{C} . \mathrm{O}_{2}$ production from $\mathrm{H}_{2} \mathrm{SO}_{4}$ requires separation from co-produced $\mathrm{SO}_{2}, \mathrm{SO}_{3}$ and $\mathrm{H}_{2} \mathrm{O}$ gaseous mixtures, while $\mathrm{H}_{2}$ requires separation from $\mathrm{HI}$ and $\mathrm{I}_{2} \cdot \mathrm{H}_{2}$ and $\mathrm{O}_{2}$ are collected via the separation process for further applications. The high temperature of $\mathrm{SO}_{3}$ decomposition $\left(>850{ }^{\circ} \mathrm{C}\right)$ can be lowered via equilibrium shift by extracting $\mathrm{O}_{2}$ from the reaction systems. Membrane-based separation methods such as microfiltration, ${ }^{8}$ ultrafiltration, ${ }^{9}$ nanofiltration, ${ }^{\mathbf{1 0}}$ reverse osmosis, $^{\mathbf{1 1}}$ and gas separation $^{\mathbf{1 2}}$ consume the least amount of energy compared with other separation techniques. ${ }^{13}$ Membrane processes also provide a significant, convenient, and sustainable solution for $\mathrm{H}_{2}$ and $\mathrm{O}_{2}$ separation. ${ }^{\mathbf{1 4 - 1 8}}$

In recent years, several types of membranes have been developed for the iodine-sulfur cycle.,.$^{\mathbf{4 1 9 - 2 8}}$ Myagmarjav et al. reported that a hexyltrimethoxysilane (HTMOS) derived silica membrane achieved $\mathrm{H}_{2}$ permeance on the order of $10^{-7} \mathrm{~mol}$ 
$\mathrm{m}^{-2} \mathrm{~s}^{-1} \mathrm{~Pa}^{-1}$ with $\mathrm{H}_{2} / \mathrm{HI}$ selectivity of more than $175 .{ }^{4}$ In addition, their silica-based ceramic membrane reactor achieved HI conversion of 0.70 and $\mathrm{H}_{2}$ extraction of 0.98 at $400{ }^{\circ} \mathrm{C}^{27}$ However, it was also reported that silica membranes can't survive under humid environments at high temperatures, ${ }^{29}$ and challenges remain for the use of silica membranes when using water in Bunsen reaction and $\mathrm{H}_{2} \mathrm{SO}_{4}$ decomposition reaction. Nomura et al. proposed a cation exchange membrane (CEM) constructed from polymerized divinylbenzene on Nafion for Bunsen reaction. ${ }^{19} \mathrm{HI}$ and $\mathrm{H}_{2} \mathrm{SO}_{4}$ were obtained separately from CEM-divided cells by feeding $\mathrm{SO}_{2}, \mathrm{I}_{2}$ and $\mathrm{H}_{2} \mathrm{O}$. He et al. discovered two Pt/carbon catalyst coated membranes (CCMs) that showed a reduced charge transfer resistance for the Bunsen reaction at room temperature. ${ }^{24}$ The electrolytic voltage was reduced by $62.7 \%$ with cathode current efficiency that reached $97.41 \%$. However, water permeated the cation exchange membrane to form $\mathrm{H}_{2} \mathrm{SO}_{4}$, and resistance to $\mathrm{H}_{2} \mathrm{SO}_{4}$ remains unsolved. Several recent results have also shown promising membrane performances under $\mathrm{H}_{2} \mathrm{SO}_{4}$ for the IS process. PTFEbased materials were reportedly stable even after exposure to highly concentrated $\mathrm{H}_{2} \mathrm{SO}_{4}$ solutions at $80-120{ }^{\circ} \mathrm{C} .{ }^{30}$ Nonfluorinated membranes (e.g., polybenzimidazole, nonfluorinated poly(arylene ether sulfone)) have also shown excellent stability against 30 and $60 \mathrm{wt} \% \mathrm{H}_{2} \mathrm{SO}_{4}$ at $80{ }^{\circ} \mathrm{C} .{ }^{31}$ However, for $\mathrm{O}_{2}$ separation in integrated $\mathrm{H}_{2} \mathrm{SO}_{4}$ decomposition systems, stability under high temperatures $\left(600-900{ }^{\circ} \mathrm{C}\right)$ for the second reaction, which is expressed as eqn (4), and for corrosion under strongly acidic conditions remains a challenge.

Generally, inorganic membranes are prepared with the strength to withstand high temperatures as well as oxidative and chemical conditions, which makes them promising candidates for $\mathrm{O}_{2}$ separation from $\mathrm{SO}_{3}$ decomposition, as mentioned in eqn (4). Notably, we reported several classes of inorganic membrane materials/metal oxides employed in membrane reactors for $\mathrm{O}_{2} / \mathrm{SO}_{3}$ separation. ${ }^{3,5} \mathrm{SiO}_{2}$ membranes, due to their excellent thermal stability and high gas selectivity, ${ }^{17,32}$ were first used by our team for $\mathrm{O}_{2} / \mathrm{SO}_{2}$ separation in 2015. ${ }^{3}$ Bis(triethoxysilyl)ethane (BTESE)-derived membranes, particularly those fabricated under high temperatures, have demonstrated high oxidation resistance and exhibited an $\mathrm{O}_{2}$ / $\mathrm{SO}_{3}$ selectivity of 10 with an $\mathrm{O}_{2}$ permeance of $2.5 \times 10^{-8} \mathrm{~mol}$ $\mathrm{m}^{-2} \mathrm{~s}^{-1} \mathrm{~Pa}^{-1} \cdot{ }^{33}$ Despite a decrease in permeance after exposure to $\mathrm{SO}_{3}$, the BTESE membrane exhibited a very high level of $\mathrm{SO}_{3}$ stability. On the other hand, highly water stable BTESE membranes have also been studied, ${ }^{17,34}$ and these have served as selective filters for $\mathrm{H}_{2} \mathrm{O} / \mathrm{O}_{2} / \mathrm{SO}_{3}$ separation. In addition, the membrane materials with high $\mathrm{SO}_{3}\left(10 \%\right.$ in $\left.\mathrm{O}_{2}\right)$ resistance at $550{ }^{\circ} \mathrm{C}$, such as $\mathrm{SiO}_{2}, \mathrm{SiO}_{2}-\mathrm{ZrO}_{2}$ (high $\mathrm{Si} / \mathrm{Zr}$ ratio), and $\alpha-\mathrm{Al}_{2} \mathrm{O}_{3}$ powders were fundamentally studied. ${ }^{5}$

To the best of our knowledge, however, no study has yet reported the chemical stability of membrane materials against sulfuric acid at high temperatures $\left(>400{ }^{\circ} \mathrm{C}\right)$, and as yet no effective strategy has been developed to fabricate an $\mathrm{O}_{2}$-selective membrane structure. Moreover, there has been no report of an attempt to apply a membrane reactor to $\mathrm{H}_{2} \mathrm{SO}_{4}$ decomposition. However, the use of high temperatures is essential for the separation of $\mathrm{O}_{2}$ though membrane and catalytic decomposition of $\mathrm{H}_{2} \mathrm{SO}_{4}$. The present study expands our previous work on the stability of various types of metal oxides under $\mathrm{SO}_{3}$ exposure, ${ }^{5}$ and provides insight from evaluating the characteristics of $\mathrm{SiO}_{2}, \mathrm{ZrO}_{2}, \mathrm{SiC}$, homemade $\mathrm{Al}_{2} \mathrm{O}_{3}, \mathrm{SiO}_{2}-\mathrm{ZrO}_{2}$, and $\alpha-\mathrm{Al}_{2} \mathrm{O}_{3}$ under $\mathrm{H}_{2} \mathrm{SO}_{4}$ vapor at high temperatures. After clarifying the chemical stability, the $\mathrm{H}_{2} \mathrm{SO}_{4}$ decomposition conversion of the membrane fabricated by $\mathrm{SiC}$ was further studied.

\section{Experiments}

\subsection{Preparation of sol, gel and powders}

$\mathrm{SiO}_{2}-\mathrm{ZrO}_{2}$ sols with sol concentrations of $2.0 \mathrm{wt} \%$ were synthesized from tetraethoxysilane (TEOS) and zirconium butoxide solutions (ZrBT, 80\% in 1-butanol) in $\mathrm{Si} / \mathrm{Zr}$ molar ratios of $5 / 5,7 / 3$ and $10 / 0$ by hydrolysis and condensation reactions in $\mathrm{H}_{2} \mathrm{O}$ with $\mathrm{HCl}$ (35 wt\%) as the catalyst. The details can be found in our previous reports. ${ }^{5,35} \mathrm{Al}_{2} \mathrm{O}_{3}$ gels were prepared via hydrolysis and condensation by mixing aluminium tri-sec-butoxide (AlTBT, 97\%) with water, and $\mathrm{HCl}$ in molar ratios of AlTBT/ $\mathrm{H}_{2} \mathrm{O}$ / $\mathrm{HCl}=1 / 10 / 0.1 . \mathrm{ZrO}_{2}$ sol was prepared via hydrolysis and condensation by mixing $\mathrm{ZrBT}, \mathrm{H}_{2} \mathrm{O}$, and $\mathrm{HCl}$ in molar ratios of $\mathrm{ZrBT} / \mathrm{H}_{2} \mathrm{O} / \mathrm{HCl}=1 / 1 / 0.1$. Ethanol (99.5\%) was added to adjust the concentration of AlTBT or ZrBT sols at $5 \mathrm{wt} \% . \mathrm{Al}_{2} \mathrm{O}_{3}, \mathrm{SiO}_{2}$, $\mathrm{ZrO}_{2}$, and $\mathrm{SiO}_{2}-\mathrm{ZrO}_{2}$ powders were prepared by drying $\mathrm{Al}_{2} \mathrm{O}_{3}$, $\mathrm{SiO}_{2}, \mathrm{ZrO}_{2}$, and $\mathrm{SiO}_{2}-\mathrm{ZrO}_{2}(\mathrm{Si} / \mathrm{Zr}$ ratio $=7 / 3)$ gels at $50{ }^{\circ} \mathrm{C}$ and subsequently calcined at $600{ }^{\circ} \mathrm{C}$ under air for $24 \mathrm{~h}$.

\subsection{Characterizations}

After drying $\mathrm{SiO}_{2}, \mathrm{ZrO}_{2}$, homemade $\mathrm{Al}_{2} \mathrm{O}_{3}, \mathrm{SiO}_{2}-\mathrm{ZrO}_{2}(\mathrm{Si} / \mathrm{Zr}$ ratio of $7 / 3$ ), and $\mathrm{SiC}$ powders at $600{ }^{\circ} \mathrm{C}$ under air, the exposure experiment was carried out in a quartz cell in which these powders were exposed to either $\mathrm{H}_{2} \mathrm{O}$ or $\mathrm{H}_{2} \mathrm{SO}_{4}(98 \%)$ vapor under an absolute pressure of 1 bar at $600{ }^{\circ} \mathrm{C}$ for $24 \mathrm{~h}$. Then, $2 \mathrm{ml}$ of liquid $\left(\mathrm{H}_{2} \mathrm{O}\right.$ or $\left.\mathrm{H}_{2} \mathrm{SO}_{4}\right)$ was added into the quartz tube before heating, and after heating at $600{ }^{\circ} \mathrm{C}$, and the vaporized liquid was refluxed in the tube as schematically shown in the diagram in the Fig. S1. $\uparrow$ Powders were also exposed with an $\mathrm{SO}_{3}$ of $10 \mathrm{kPa}$ at $600{ }^{\circ} \mathrm{C}$ under sweep conditions similar to our previous report. ${ }^{5}$ Subsequently, those powders were followed by drying at $500{ }^{\circ} \mathrm{C}$ under air to remove the adsorbed gas on the surface. Then, characterizations of powders were carried out using Energy Dispersive X-ray Spectroscopy (EDS) Scanning Electron Microscopy (SEM, JCM-5700, JEOL Ltd.), X-ray diffraction (XRD, Bruker AXS, Japan), and $\mathrm{N}_{2}$ adsorption under liquid nitrogen at $77 \mathrm{~K}$ (BELMAX, BEL Japan Inc.).

\subsection{Preparation of mesoporous membranes}

Fabrication of membranes for $\mathrm{H}_{2} \mathrm{SO}_{4}$ separation, $\alpha-\mathrm{Al}_{2} \mathrm{O}_{3}$ membrane support (cylindrical porous tubes with average pore size $2 \mu \mathrm{m}$; outer diameter $1 \mathrm{~cm}$; length $10 \mathrm{~cm}$, Nikkato. Corp.) were used as substrates. 5 types membranes were fabricated as shown in Table 1. The outer surfaces of the tube were coated with $\alpha$-alumina (2.0 and $0.2 \mu \mathrm{m}$, Sumitomo Chemical Co., Ltd) or silicon carbide (2.3 and $0.5 \mu \mathrm{m}$, Pacific Rundum Co., Ltd.) particles mixed with the sols $\left(\mathrm{SiO}_{2}-\mathrm{ZrO}_{2}\right.$ at $\mathrm{Si} / \mathrm{Zr}$ ratio of $5 / 5,7 / 3$ 
Table 1 Conditions of the membrane fabrication by using various particles and binder sols

\begin{tabular}{lll}
\hline No. & Particles & Binder sols \\
\hline M1 & - & - \\
M2 & $\alpha-\mathrm{Al}_{2} \mathrm{O}_{3}$ & $\mathrm{SiO}_{2}-\mathrm{ZrO}_{2}(5 / 5)$ \\
M3 & $\alpha-\mathrm{Al}_{2} \mathrm{O}_{3}$ & $\mathrm{SiO}_{2}-\mathrm{ZrO}_{2}(7 / 3)$ \\
M4 & $\mathrm{SiC}$ & $\mathrm{SiO}_{2}-\mathrm{ZrO}_{2}(7 / 3)$ \\
M5 & $\mathrm{SiC}$ & $\mathrm{SiO}_{2}-\mathrm{ZrO}_{2}(10 / 0)$
\end{tabular}

or $10 / 0$ ) as the binder to create a smooth and homogeneous surface, followed by firing at $600{ }^{\circ} \mathrm{C}$ for $15 \mathrm{~min}$ then cooling to room temperature. This procedure of coating particle layers was repeated several times to reduce the pore sizes of the membranes to approximately $20 \mathrm{~nm}$. The schematic membrane structure is shown in Fig. 1.

\subsection{Gas permeance of membranes and $\mathrm{H}_{2} \mathrm{SO}_{4}$ conversion}

The gas permeation of membranes during $\mathrm{H}_{2} \mathrm{SO}_{4}$ and $\mathrm{H}_{2} \mathrm{O}$ exposure was tested in membrane module shown schematically in Fig. 2. Distilled $\mathrm{H}_{2} \mathrm{O}\left(0.48 \mathrm{ml} \mathrm{h}^{-1}\right)$ or $\mathrm{H}_{2} \mathrm{SO}_{4}\left(1.0 \mathrm{ml} \mathrm{h}^{-1}\right)$ was introduced into the membrane via a syringe pump, and helium was supplied as a carrier gas (flow rate of $90 \mathrm{ml} \mathrm{min}^{-1}$ ) to control the molar ratio of $\mathrm{H}_{2} \mathrm{O}$ or $\mathrm{H}_{2} \mathrm{SO}_{4}$ at 0.1 bar. Membranes of different types, M1-M5, were placed in an electric furnace with a controlled inner-side temperature of $600{ }^{\circ} \mathrm{C}$ for evaporation and reaction. Once $\mathrm{H}_{2} \mathrm{SO}_{4}$ was injected inside the heated zone, liquid $\mathrm{H}_{2} \mathrm{SO}_{4}$ was evaporated, and then thermally decomposed into sulfur trioxide and water vapor. After exposure tests for several hours, membranes were dried with $\mathrm{N}_{2}$ flow in the furnace at $600{ }^{\circ} \mathrm{C}$, followed by cooling to room temperature. Then, the membrane module and gas lines were carefully cleaned by water to wash out the remaining $\mathrm{H}_{2} \mathrm{SO}_{4}$ and dried in an $80{ }^{\circ} \mathrm{C}$ oven. Pure gas permeance was measured under the transmembrane pressure difference from 0.01 to 1 bar by feeding gas to the outside of the membrane.

An M4 membrane was used for the membrane reactor to An M4 membrane was used for the membrane reactor to investigate the effect of $\mathrm{O}_{2}$ extraction on $\mathrm{H}_{2} \mathrm{SO}_{4}$ decomposition conversion. At $600{ }^{\circ} \mathrm{C}$, the liquid sulphuric acid changes to a gas phase, and the decomposition reaction can be split into two

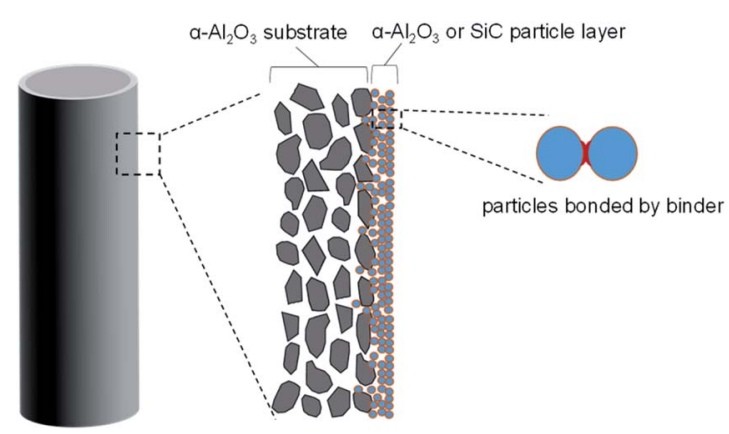

Fig. 1 The schematic structure of $\alpha-\mathrm{Al}_{2} \mathrm{O}_{3}$ or $\mathrm{SiC}$ particle membranes. endothermic sub-reactions. The first sub-reaction is the dissociation of sulphuric acid into sulphur trioxide and water (reaction (3)), and the second is the decomposition of sulphur trioxide into sulphur dioxide and oxygen (reaction (4)). Here, $\mathrm{SO}_{3}$ was decomposed to $\mathrm{SO}_{2}$ with the $\mathrm{Pt} / \mathrm{Al}_{2} \mathrm{O}_{3}$ catalyst $(1.5 \mathrm{~g}$, Shimadzu Corporation), which was packed inside the membrane. Outlet gases from the membrane reactor, consisting of mixtures of carrier gas $\mathrm{He}$, and $\mathrm{H}_{2} \mathrm{O}, \mathrm{SO}_{3}, \mathrm{SO}_{2}$, and $\mathrm{O}_{2}$, as produced from $\mathrm{H}_{2} \mathrm{SO}_{4}$ decomposition, subsequently passed through two bottles filled with $120 \mathrm{ml}$ sodium hydroxide aqueous solution (20 wt $\%$ ), where $\mathrm{H}_{2} \mathrm{O}$ was condensed and $\mathrm{SO}_{3}$ or $\mathrm{SO}_{2}$ was trapped by the neutralization reaction. So the outlet gas consisted of $\mathrm{He}$ and $\mathrm{O}_{2}$ and was measured using a soap film bubble flowmeter. $\mathrm{NaOH}$ was chosen for acidic gas absorption because it had high efficiency (nearly $100 \%$ ) with $\mathrm{SO}_{2}$ removal. ${ }^{36}$ For safety, a $\mathrm{SO}_{2}$ alarm (ToxiRAE II, PGM-1130) was set nearby the equipment to signal $\mathrm{SO}_{2}$ leakage, and the outlet gas in the $\mathrm{NaOH}$ trap was monitored by the $\mathrm{SO}_{2}$ alarm and the $\mathrm{SO}_{2}$ content was found to be lower than $1 \mathrm{ppm}$.

$\mathrm{H}_{2} \mathrm{SO}_{4}$ conversion $(w)$ can be quantified by the ratio of produced $\mathrm{O}_{2}$ over theoretical $\mathrm{O}_{2}$ since $1 \mathrm{~mol}$ of $\mathrm{H}_{2} \mathrm{SO}_{4}$ can produce $0.5 \mathrm{~mol}$ of $\mathrm{O}_{2}$ after complete conversion. Therefore, the conversion can be expressed in the following equation:

$$
w=\frac{F_{\mathrm{r}}+F_{\mathrm{p}}-F_{\mathrm{c}}}{0.5 F_{\mathrm{h}}} \times 100 \%
$$

In that equation, $F_{\mathrm{r}}$ and $F_{\mathrm{p}}$ are the gas molar rate $\left(\mathrm{mol} \mathrm{s}{ }^{-1}\right)$ of retentate and permeate side of the membrane, $F_{\mathrm{c}}$ is the molar rate of carried gas He. $F_{\mathrm{h}}\left(\mathrm{mol} \mathrm{s}^{-1}\right)$ is the feed rate of liquid $\mathrm{H}_{2} \mathrm{SO}_{4}$. It is of note that $\mathrm{H}_{2} \mathrm{SO}_{4}$ was $100 \%$ decomposed to $\mathrm{H}_{2} \mathrm{O}$ and $\mathrm{SO}_{3}$ at $450{ }^{\circ} \mathrm{C}$, hence, from this perspective, the $\mathrm{H}_{2} \mathrm{SO}_{4}$ conversion to $\mathrm{SO}_{2}$ was dominated by $\mathrm{SO}_{3}$ decomposition.

\section{Results and discussion}

\subsection{Stability of membrane materials under $\mathrm{H}_{2} \mathrm{SO}_{4}$ exposure}

It has been pointed out that the $\alpha-\mathrm{Al}_{2} \mathrm{O}_{3}, \mathrm{SiO}_{2}$ and lower-Zrcontent $\mathrm{SiO}_{2}-\mathrm{ZrO}_{2}$ powders had good chemical stability against $\mathrm{SO}_{2}$ and $\mathrm{SO}_{3}$ even at $550{ }^{\circ} \mathrm{C}$ for $\mathrm{O}_{2} / \mathrm{SO}_{2}$ or $\mathrm{O}_{2} / \mathrm{SO}_{3}$ separation. ${ }^{5,37}$ The $\mathrm{H}_{2} \mathrm{SO}_{4}$ decomposition generates water vapor at temperatures higher than $300{ }^{\circ} \mathrm{C}$, and, hence, the stability and corrosion under steam/acid still needs to be addressed. Therefore, Fig. 3 depicts the XRD patterns of the samples after being treated in $\mathrm{SO}_{3}$ or $\mathrm{H}_{2} \mathrm{SO}_{4}$ vapor at $600{ }^{\circ} \mathrm{C}$ for $24 \mathrm{~h}$. The XRD patterns of $\mathrm{SiO}_{2}$ (Fig. 3A) showed a broad single peak centered at $23^{\circ}$, which was assigned to an amorphous $\mathrm{SiO}_{2}$ phase, and no other peaks were observed in the XRD patterns. Additionally, Nadar et al. also reported that TG-DTA and XRD patterns of $\mathrm{SiO}_{2}$ after $\mathrm{H}_{2} \mathrm{SO}_{4}$ exposure were similar to those before $\mathrm{H}_{2} \mathrm{SO}_{4}{ }^{38}$ indicating the high acid resistance of $\mathrm{SiO}_{2}$. Table 2 shows the BET area of $\mathrm{SiO}_{2}$ powders was largely decreased after being treated in steam and in $\mathrm{H}_{2} \mathrm{SO}_{4}$ vapor. The reason for this decrease in the BET area could have centered around the reaction of $\mathrm{Si}-\mathrm{O}-\mathrm{Si}$ and $\mathrm{H}_{2} \mathrm{O}$ to form $\mathrm{Si}-\mathrm{OH}$, which could have led to large non-selective pores and resultant particles that became dense. ${ }^{34,39} \mathrm{XRD}$ analyses of $\alpha-\mathrm{Al}_{2} \mathrm{O}_{3}$ (Fig. 3B) powders revealed that the $\mathrm{S}$ in $\mathrm{Al}_{2}\left(\mathrm{SO}_{4}\right)_{3}$ and the percentage of sulfur/aluminum 


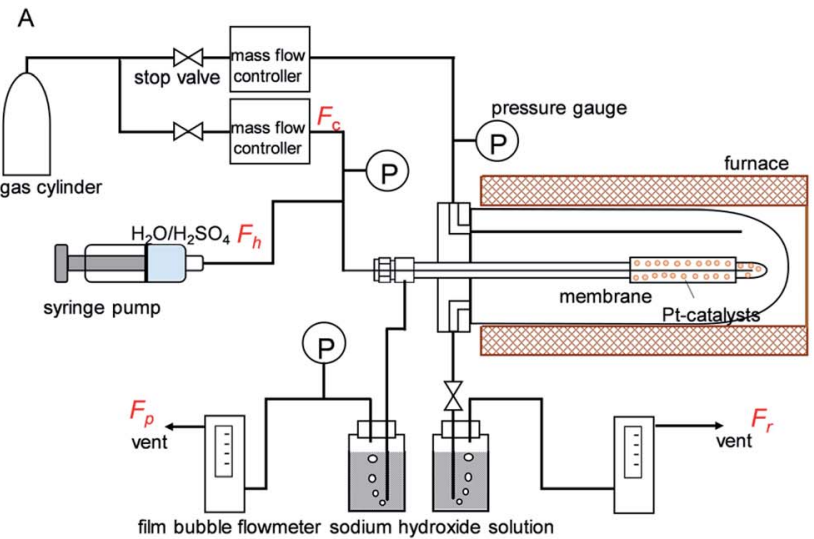

B

Fig. 2 (A) Schematic diagram of the experiment for steam and sulphuric acid treatment and gas permeance measurement. (B) Schematic illustration of the $\mathrm{SiC}$ membrane used membrane reactor for $\mathrm{H}_{2} \mathrm{SO}_{4}$ decomposition.

detected by EDS had increased from 0.87 to $26 \%$, as shown in Table 2. Also, the FT-IR spectra confirmed that an $\mathrm{SO}_{4}$ peak was formed in $\alpha-\mathrm{Al}_{2} \mathrm{O}_{3}$ (ESI- $\left.+\dagger\right)$, which was attributed to the reaction of alumina with the $\mathrm{H}_{2} \mathrm{SO}_{4}$ vapor at $600{ }^{\circ} \mathrm{C}$. Furthermore, BET analyses revealed how the surface area of $\alpha-\mathrm{Al}_{2} \mathrm{O}_{3}$ had decreased from 8.8 to $1.9 \mathrm{~m}^{2} \mathrm{~g}^{-1}$ following exposure to $\mathrm{H}_{2} \mathrm{SO}_{4}$, presumably due to the formation of $\mathrm{Al}_{2}\left(\mathrm{SO}_{4}\right)_{3}$ on the surface, which reduced the size of the pores. Regarding the homemade $\mathrm{Al}_{2} \mathrm{O}_{3}$ powder, which had a high surface area of $226 \mathrm{~m}^{2} \mathrm{~g}^{-1}$ compared with that of crystalline $\alpha-\mathrm{Al}_{2} \mathrm{O}_{3}$ at $8.8 \mathrm{~m}^{2} \mathrm{~g}^{-1}$, the BET area was drastically decreased after exposure to $\mathrm{SO}_{3}$ and $\mathrm{H}_{2} \mathrm{SO}_{4}$, but the reactivity was significantly greater under $\mathrm{H}_{2} \mathrm{SO}_{4}$ vapor than under $\mathrm{SO}_{3}$. Fig. 3C shows the XRD of $\mathrm{ZrO}_{2}$, which exhibited an increased crystalline monoclinic $(\mathrm{m}) \mathrm{ZrO}_{2}$ from the tetragonal $(\mathrm{t})$ phase $^{40}$ due to the temperature swings of the membrane furnace and the dryer oven. XRD analysis did not detect the sulfate phase for $\mathrm{ZrO}_{2}$ and $\mathrm{SiO}_{2}-\mathrm{ZrO}_{2}(\mathrm{Si} / \mathrm{Zr}=7 / 3)$ powders after $\mathrm{SO}_{3}$ exposure, as shown in Fig. $3 \mathrm{C}$ and $\mathrm{D}$, and corresponded to low $\mathrm{S}$ ratios of 2.7
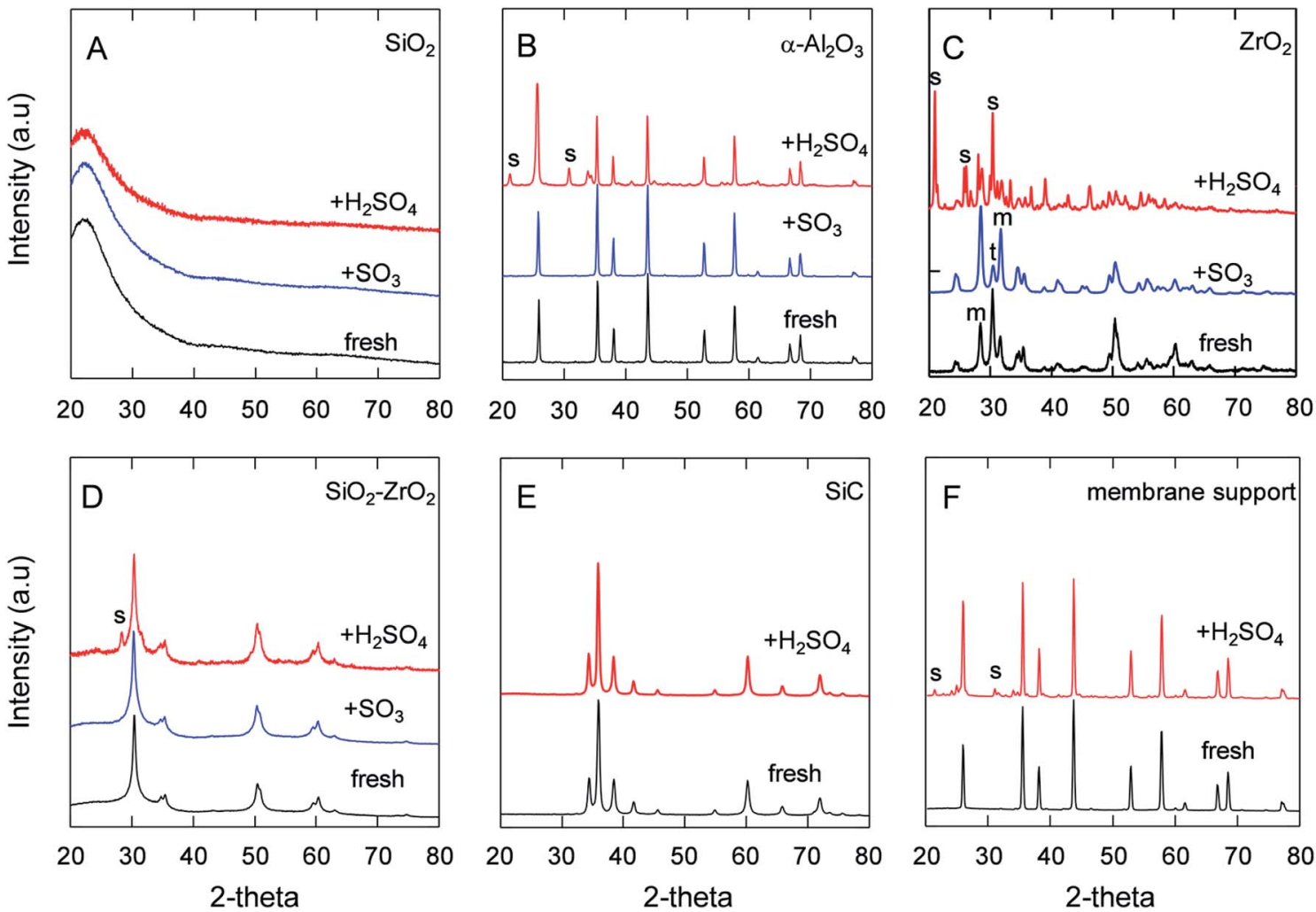

Fig. 3 XRD of different powders after $\mathrm{SO}_{3}$ or $\mathrm{H}_{2} \mathrm{SO}_{4}$ exposure at $600{ }^{\circ} \mathrm{C}$ under one-atmosphere pressure. S: zirconium sulfate or aluminum sulfate, $\mathrm{t} / \mathrm{m}$ : tetragonal/monoclinic $\mathrm{ZrO}_{2}$. (A) Home-made $\mathrm{SiO}_{2}$. (B) $\alpha-\mathrm{Al}_{2} \mathrm{O}_{3}$. (C) $\mathrm{ZrO}_{2}$. (D) $\mathrm{SiO}_{2}-\mathrm{ZrO}_{2}\left(\mathrm{Si} / \mathrm{Zr}=7 / 3\right.$ ). (E) $\mathrm{SiC}$. (F) $\alpha-\mathrm{Al} 2 \mathrm{O}_{3} \mathrm{membrane}$ support. 
Table 2 BET area and $\mathrm{S}$ ratio of powders after $\mathrm{H}_{2} \mathrm{O}$ or $\mathrm{H}_{2} \mathrm{SO}_{4}$ exposure

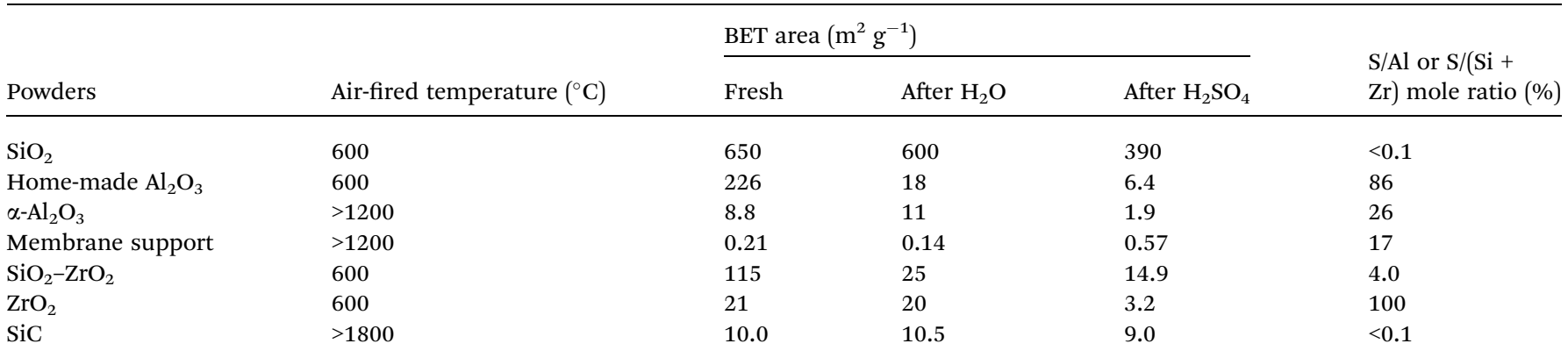

and $2.2 \%,{ }^{5}$ respectively. On the contrary, after exposure to $\mathrm{H}_{2} \mathrm{SO}_{4}$ vapor at the same temperature of $600{ }^{\circ} \mathrm{C}$, the $\mathrm{S}$ ratio was quite different between $\mathrm{ZrO}_{2}$ and $\mathrm{SiO}_{2}-\mathrm{ZrO}_{2}$ powders. The XRD spectra in Fig. 3C shows the formation of $\mathrm{Zr}\left(\mathrm{SO}_{4}\right)_{2}$ from $\mathrm{ZrO}_{2}$ after $\mathrm{H}_{2} \mathrm{SO}_{4}$ exposure, with only a small amount of crystalline $\mathrm{Zr}\left(\mathrm{SO}_{4}\right)_{2}$ (S peak) ${ }^{41}$ detected for $\mathrm{SiO}_{2}-\mathrm{ZrO}_{2}$ (Fig. 3D). In addition, Table 2 shows the $\mathrm{S}$ content measured by EDS was almost 100 and $4.0 \%$ for $\mathrm{ZrO}_{2}$ and $\mathrm{SiO}_{2}-\mathrm{ZrO}_{2}$ powders, respectively. Probable reasons for the high sulfur composition in $\mathrm{ZrO}_{2}$ powders after exposure to $\mathrm{H}_{2} \mathrm{SO}_{4}$ vapor could be primarily that $\mathrm{H}_{2} \mathrm{O}$ activated $\mathrm{ZrO}_{2}$ and formed $\mathrm{ZrO}(\mathrm{OH})_{2}$ or $\mathrm{Zr}(\mathrm{OH})_{4}$ at high temperature. $^{\mathbf{4 2}}$ Another explanation could be that either $\mathrm{ZrO}(\mathrm{OH})_{2}$ or $\mathrm{Zr}(\mathrm{OH})_{4}$ was more active in the reaction with $\mathrm{SO}_{3}$ to form $\mathrm{Zr}\left(\mathrm{SO}_{4}\right)_{2}$. Fig. 3E shows the XRD spectra of silicon-carbide powders before and after $\mathrm{H}_{2} \mathrm{SO}_{4}$ exposure. No change in peaks was observed, probably because SiC is generally known for its ultrahigh chemical and thermal stability. ${ }^{\mathbf{4 3 - 4 5}}$ Additionally, the $\alpha-\mathrm{Al}_{2} \mathrm{O}_{3}$ membrane supports used in this study were proven to be chemically stable under $\mathrm{H}_{2} \mathrm{SO}_{4}$, which was confirmed by XRD analysis to have a lesser amount of aluminum sulfate (Fig. $3 \mathrm{~F}$ ) compared with that of $\alpha-\mathrm{Al}_{2} \mathrm{O}_{3}$ powders (Fig. 3B). This was probably because $\mathrm{SiO}_{2}$ was added to the $\mathrm{Al}_{2} \mathrm{O}_{3}$ membrane supports since $\mathrm{Si}$ was detected in the $\mathrm{Al}_{2} \mathrm{O}_{3}$ membrane supports, although the exact content was not available. Although the $\mathrm{S}$ content was $17 \%$ for $\alpha-\mathrm{Al}_{2} \mathrm{O}_{3}$ membrane supports after $\mathrm{H}_{2} \mathrm{SO}_{4}$ exposure, the change in the element composition of the substrates had less of an effect on gas permeation (Fig. 5). To benefit the stability of these materials against $\mathrm{H}_{2} \mathrm{SO}_{4}$ in the IS
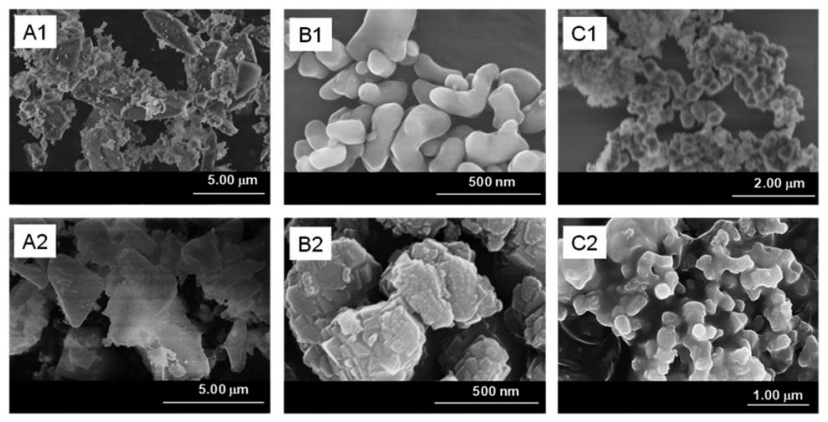

Fig. $4 \mathrm{SEM}$ of fresh $\mathrm{SiO}_{2}$ (A1), $\boldsymbol{\alpha}-\mathrm{Al}_{2} \mathrm{O}_{3}$ (B1), $\mathrm{ZrO}_{2}$ (C1) powders. (A2), (B2) and (C2) were those powders after $\mathrm{H}_{2} \mathrm{SO}_{4}(100 \mathrm{kPa})$ exposure at $600{ }^{\circ} \mathrm{C}$, respectively. process, the use of $\alpha-\mathrm{Al}_{2} \mathrm{O}_{3}$ membrane supports, $\mathrm{SiC}$ and $\mathrm{SiO}_{2}-$ $\mathrm{ZrO}_{2}$ were proposed for the preparation of SiC membranes.

Fig. 4 features the SEM micrographs of $\mathrm{SiO}_{2}, \alpha-\mathrm{Al}_{2} \mathrm{O}_{3}$ and $\mathrm{ZrO}_{2}$ before and after exposure to $\mathrm{H}_{2} \mathrm{SO}_{4}$. As shown in the images of Fig. $4 \mathrm{~A} 1$ and $\mathrm{A} 2$, the surface of $\mathrm{SiO}_{2}$ powders were smooth after $\mathrm{H}_{2} \mathrm{SO}_{4}$ exposure, which demonstrated morphological differences between the fresh state and after $\mathrm{SO}_{3}$ exposure $^{5}$ while maintaining approximately the same particle size. This could be explained by the densification of $\mathrm{SiO}_{2}$ fine particles induced by the reaction between $\mathrm{Si}-\mathrm{O}-\mathrm{Si}$ and $\mathrm{H}_{2} \mathrm{O}$. Fig. 4B1 and $\mathrm{B} 2$ shows that $\alpha-\mathrm{Al}_{2} \mathrm{O}_{3}$ particles had a relatively uniform morphology even after $\mathrm{H}_{2} \mathrm{SO}_{4}$ exposure while the size of the $\mathrm{Al}_{2} \mathrm{O}_{3}$ particles grew larger due to the formation of low-melting $\mathrm{Al}_{2}\left(\mathrm{SO}_{4}\right)_{3}$ on the surface, with which each of the primary particles seemed to be connected and aggregated that differed from the $\alpha-\mathrm{Al}_{2} \mathrm{O}_{3}$ particles with $\mathrm{SO}_{3}$ exposure. ${ }^{5}$ Given that $\alpha-\mathrm{Al}_{2} \mathrm{O}_{3}$ particles after exposure were deposited with, and covered by, the $\mathrm{Al}_{2}\left(\mathrm{SO}_{4}\right)_{3}$, these SEM photos confirm the compositions obtained by EDS. The SEM images in Fig. 4C1 and $\mathrm{C} 2$ also show that the fine $\mathrm{ZrO}_{2}$ particles had reacted with the $\mathrm{H}_{2} \mathrm{SO}_{4}$ vapor and increased in size, which is similar to the growth of $\alpha-\mathrm{Al}_{2} \mathrm{O}_{3}$ powder under $\mathrm{H}_{2} \mathrm{SO}_{4}$ exposure, probably due to the effect of dissolution under the $\mathrm{H}_{2} \mathrm{O}$ vapor and to the reaction with $\mathrm{SO}_{3}$.

\subsection{Permeance of the $\mathrm{SiC}$ membrane reactor for $\mathrm{H}_{2} \mathrm{SO}_{4}$ decomposition}

Porous inorganic membranes were first explored under an extreme condition, i.e., $\mathrm{H}_{2} \mathrm{SO}_{4}$ decomposition at $600{ }^{\circ} \mathrm{C}$. Fig. 5

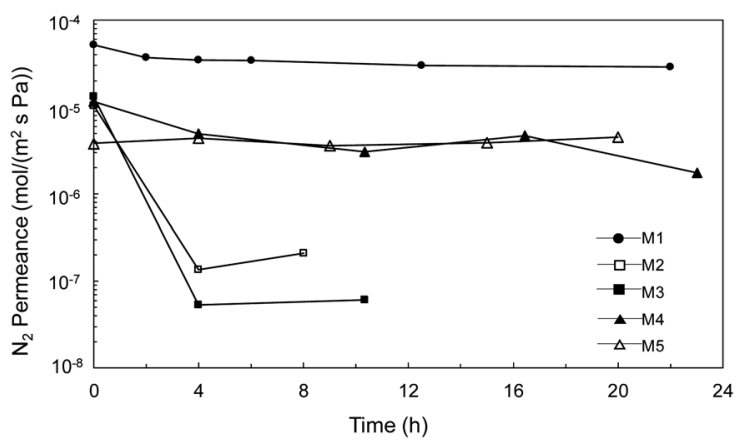

Fig. 5 Time course of $\mathrm{N}_{2}$ permeance for $\alpha-\mathrm{Al}_{2} \mathrm{O}_{3}$ membrane support (M1) and membrane prepared by $\mathrm{Al}_{2} \mathrm{O}_{3}$ particle layer (M2, M3), and $\mathrm{SiC}$ particle (M4, M5) after the treatment under $\mathrm{H}_{2} \mathrm{SO}_{4}$ vapor at $600{ }^{\circ} \mathrm{C}$. 
shows the time course of the $\mathrm{N}_{2}$ permeance with increases in the treatment time under $\mathrm{H}_{2} \mathrm{SO}_{4}$ vapor. The $\mathrm{N}_{2}$ permeance of the $\alpha-\mathrm{Al}_{2} \mathrm{O}_{3}$ membrane support (M1) was decreased only slightly even after $22 \mathrm{~h}$ of exposure to $\mathrm{H}_{2} \mathrm{SO}_{4}$ vapor at $600{ }^{\circ} \mathrm{C}$, since the membrane support provided only moderate chemical stability, as shown in Fig. 3F (XRD) and Table 2, and the large pores changed very little even after sulfate formation. M2, M3, and M4 prepared with different particles $\left(\mathrm{SiC}, \alpha-\mathrm{Al}_{2} \mathrm{O}_{3}\right.$ ) and binders $\left(\mathrm{SiO}_{2}-\mathrm{ZrO}_{2}, \mathrm{SiO}_{2}\right)$ showed $\mathrm{N}_{2}$ permeance at the same level $\left(10^{-5} \mathrm{~mol} \mathrm{~m}^{-2} \mathrm{~s}^{-1} \mathrm{~Pa}^{-1}\right)$ as before the stability test, which provided a fair comparison and verified good reproducibility of the membrane fabrication. Values were drastically decreased for the permeance of both $\mathrm{M} 2$ and $\mathrm{M} 3 \mathrm{Al}_{2} \mathrm{O}_{3}$ particle layers following $\mathrm{H}_{2} \mathrm{SO}_{4}$ exposure for $4 \mathrm{~h}$. The permeance of $\mathrm{M} 2$ was further decreased, however, confirming that the high $\mathrm{Zr}$ content in the binder $(\mathrm{Si} / \mathrm{Zr}=5 / 5)$ was more unstable due to the formation of $\mathrm{Zr}\left(\mathrm{SO}_{4}\right)_{2}$ with $\mathrm{H}_{2} \mathrm{SO}_{4}$, similar to high $\mathrm{Zr}$ content $\mathrm{SiO}_{2}-\mathrm{ZrO}_{2}(\mathrm{Si} / \mathrm{Zr}=5 / 5)$ in $\mathrm{SO}_{3} .{ }^{5}$ These results were reasonable, and strongly suggested that the membranes should be prepared using Si-rich $\mathrm{SiO}_{2}-\mathrm{ZrO}_{2}(\mathrm{Si} / \mathrm{Zr}=7 / 3)$ as a binder. $\mathrm{M} 4$ and $\mathrm{M} 5 \mathrm{SiC}$ particle layers showed a very small decrease and high relative permeance over all the particle membranes, M2-M5. That indicated that the membrane prepared by $\mathrm{SiC}$ with $\mathrm{Si}$-rich $\mathrm{SiO}_{2}-$ $\mathrm{ZrO}_{2}(\mathrm{Si} / \mathrm{Zr}=7 / 3)$ increased both the chemical and hydrothermal stability compared with that of the $\mathrm{Al}_{2} \mathrm{O}_{3}$ particle layers with $\mathrm{Zr}$-rich $\mathrm{SiO}_{2}-\mathrm{ZrO}_{2}$ used to fabricate $\mathrm{M} 2$ and $\mathrm{M}$. The morphology changed less for membranes fabricated with SiC layers following exposure to $\mathrm{H}_{2} \mathrm{SO}_{4}$ (ESI- $3 \dagger$ ), which corresponds to the stability confirmed by XRD and BET results. These results suggested that the $\mathrm{SiC}$ was stable for fabricating a particle layer for membrane preparation in the IS process.

Catalytic membrane reactor for $\mathrm{H}_{2} \mathrm{SO}_{4}$ decomposition, liquid $\mathrm{H}_{2} \mathrm{SO}_{4}(98 \%)$ was fed at a flow rate of $1.0 \mathrm{ml} \mathrm{h}^{-1}$ and He was used as the carrier gas with a flow rate of $24.5 \mathrm{ml} \mathrm{min} \mathrm{m}^{-1}$ controlled by a mass flow controller. Fig. 6 shows the time course for the total flow rate of the outlet gas in both the retentate and permeate, and the conversion of $\mathrm{H}_{2} \mathrm{SO}_{4}$ decomposition at $600{ }^{\circ} \mathrm{C}$ in a $\mathrm{SiC}$ particlederived membrane reactor. A brief flow sheet with or without extraction is shown in ESI-4. $\dagger$ The membrane reactor with extraction, $\mathrm{O}_{2}$ with low molecular weight was transferred faster than $\mathrm{SO}_{2}$ and $\mathrm{SO}_{3}$, and $\mathrm{SO}_{3}$, and the largest molecular weight, permeated at the slowest speed by Knudsen diffusion through the

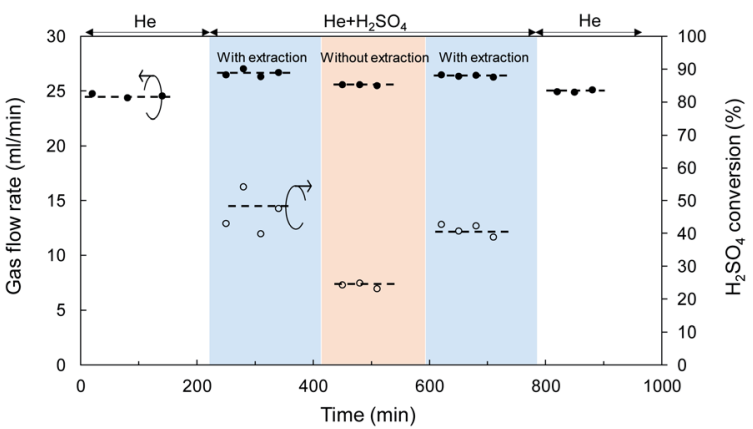

Fig. 6 Time course of gas flow rate and $\mathrm{H}_{2} \mathrm{SO}_{4}$ conversion for a $\mathrm{SiC}$ membrane tested in the catalytic membrane reactor at $600{ }^{\circ} \mathrm{C}$. mesoporous SiC membrane. ${ }^{46}$ Therefore, the equilibrium of the reaction ( $\mathrm{R} 4)\left(\mathrm{SO}_{3} \leftrightarrow \mathrm{SO}_{2}+0.5 \mathrm{O}_{2}\right)$ was forwarded to the product side by removing $\mathrm{O}_{2}$. In a comparison with a membrane without extraction, the membrane reactor with extraction achieved higher conversion at the same temperature of $600{ }^{\circ} \mathrm{C}$. The catalytic membrane reactor obtained conversion of $25 \%$ without extraction, which approximated the equilibrium (theoretical) conversion of $\mathrm{SO}_{3}$ decomposition (eqn (4)) of $28 \%$ at $900 \mathrm{~K}^{3}$ Comparison with membrane without extraction, the conversion of $\mathrm{H}_{2} \mathrm{SO}_{4}$ decomposition was increased to $45 \%$, which was much higher at the same temperature of $600{ }^{\circ} \mathrm{C}$. Additionally, the $\mathrm{H}_{2} \mathrm{SO}_{4}$ decomposition conversion remained constant at around $41 \%$ after membrane exposure to $\mathrm{H}_{2} \mathrm{SO}_{4}$ vapor for $10 \mathrm{~h}$. Moreover, after decomposition for $10 \mathrm{~h}$, He permeance was approximately the same as that before the decomposition reaction, which indicated that the $\mathrm{SiC}$ particle layer (with $\mathrm{SiO}_{2}-\mathrm{ZrO}_{2}$ ) had high hydrothermal and chemical stability under $\mathrm{H}_{2} \mathrm{O}$ and $\mathrm{SO}_{3}$. However, the separation properties of M4 membranes was still poor; the $\mathrm{He} / \mathrm{N}_{2}$ permeance ratio was 2.3 with $\mathrm{N}_{2}$ permeance of $4.5 \times 10^{-5} \mathrm{~mol} \mathrm{~m}^{-2}$ $\mathrm{s}^{-1} \mathrm{~Pa}^{-1}$, since the SiC membrane was fabricated using SiC particles, and the gaps between particles were large enough to allow gas to pass through.

\section{Conclusions}

SiC mesoporous membranes were successfully prepared using an $\alpha-\mathrm{Al}_{2} \mathrm{O}_{3}$ support and a SiC particle layer. The gas permeance of the $\mathrm{SiC}$ membrane was stable for $20 \mathrm{~h}$ under $\mathrm{H}_{2} \mathrm{SO}_{4}$ vapor at $600{ }^{\circ} \mathrm{C}$, which indicated its high chemical stability. Regarding the $\mathrm{H}_{2} \mathrm{SO}_{4}$ decomposition reaction, the $\mathrm{SiC}$ membrane achieved a conversion of $41 \%$ at $600{ }^{\circ} \mathrm{C}$, which was much higher than that of the membrane without extraction (25\%). Our previous work involved the preliminary use of SiC membranes in a catalytic membrane reactor for hydrogen production in the iodinesulfur process, and a desirable design for a SiC subnanoporous membrane with a combination of high $\mathrm{O}_{2}$ permeance and $\mathrm{O}_{2}$ / $\mathrm{SO}_{2}$ selectivity will be a major objective in the future.

\section{Conflicts of interest}

There are no conflicts to declare.

\section{Acknowledgements}

This work was supported by the Cross-ministerial Strategic Innovation Promotion Program (SIP) of the Energy Carrier Project of the Japan Science and Technology Agency (JST) and the Japan Society for the Promotion of Science (JSPS) KAKENHI Grant Number JP20H052279.

\section{Notes and references}

1 S. Kasahara, G.-J. Hwang, H. Nakajima, H.-S. Choi, K. Onuki and M. Nomura, Effects of process parameters of the IS process on total thermal efficiency to produce hydrogen from water, J. Chem. Eng. Jpn., 2003, 36, 887-899. 
2 D. M. Ginosar, H. W. Rollins, L. M. Petkovic, K. C. Burch and M. J. Rush, High-temperature sulfuric acid decomposition over complex metal oxide catalysts, Int. J. Hydrogen Energy, 2009, 34, 4065-4073.

3 L. Meng, M. Kanezashi and T. Tsuru, Catalytic membrane reactors for $\mathrm{SO}_{3}$ decomposition in iodine-sulfur thermochemical cycle: a simulation study, Int. J. Hydrogen Energy, 2015, 40, 12687-12696.

4 O. Myagmarjav, A. Ikeda, N. Tanaka, S. Kubo and M. Nomura, Preparation of an $\mathrm{H}_{2}$-permselective silica membrane for the separation of $\mathrm{H}_{2}$ from the hydrogen iodide decomposition reaction in the iodine-sulfur process, Int. J. Hydrogen Energy, 2017, 42, 6012-6023.

5 X. Yu, L. Meng, H. Nagasawa, M. Kanezashi, M. Machida and T. Tsuru, Evaluating the chemical stability of metal oxides in $\mathrm{SO}_{3}$ and applications of $\mathrm{SiO}_{2}$-based membranes to $\mathrm{O}_{2} / \mathrm{SO}_{3}$ separation, J. Am. Ceram. Soc., 2019, 102, 6946-6956.

6 A. Nadar, A. M. Banerjee, M. Pai, S. S. Meena, R. Pai, R. Tewari, S. Yusuf, A. Tripathi and S. Bharadwaj, Nanostructured $\mathrm{Fe}_{2} \mathrm{O}_{3}$ dispersed on $\mathrm{SiO}_{2}$ as catalyst for high temperature sulfuric acid decomposition-structural and morphological modifications on catalytic use and relevance of $\mathrm{Fe}_{2} \mathrm{O}_{3}-\mathrm{SiO}_{2}$ interactions, Appl. Catal., B, 2017, 217, 154-168.

7 M. Nomura, Application of an electrochemical membrane reactor to the thermochemical water splitting IS process for hydrogen production, J. Membr. Sci., 2004, 240, 221-226. 8 X. Liu, B. Jiang, X. Yin, H. Ma and B. S. Hsiao, Highly permeable nanofibrous composite microfiltration membranes for removal of nanoparticles and heavy metal ions, Sep. Purif. Technol., 2020, 233, 115976.

9 P. H. Duong, V. A. Kuehl, B. Mastorovich, J. O. Hoberg, B. A. Parkinson and K. D. Li-Oakey, Carboxylfunctionalized covalent organic framework as a twodimensional nanofiller for mixed-matrix ultrafiltration membranes, J. Membr. Sci., 2019, 574, 338-348.

10 S. Anisah, W. Puthai, M. Kanezashi, H. Nagasawa and T. Tsuru, Preparation, characterization, and evaluation of $\mathrm{TiO}_{2}-\mathrm{ZrO}_{2}$ nanofiltration membranes fired at different temperatures, J. Membr. Sci., 2018, 564, 691-699.

11 G. Dong, H. Nagasawa, L. Yu, M. Guo, M. Kanezashi, T. Yoshioka and T. Tsuru, Energy-efficient separation of organic liquids using organosilica membranes via a reverse osmosis route, J. Membr. Sci., 2020, 597, 117758.

12 Y. Ying, M. Tong, S. Ning, S. K. Ravi, S. B. Peh, S. C. Tan, S. J. Pennycook and D. Zhao, Ultrathin Two-Dimensional Membranes Assembled by Ionic Covalent Organic Nanosheets with Reduced Apertures for Gas Separation, $J$. Am. Chem. Soc., 2020, 142, 4472-4480.

13 C. Z. Liang, T.-S. Chung and J.-Y. Lai, A review of polymeric composite membranes for gas separation and energy production, Prog. Polym. Sci., 2019, 97, 101141.

14 L. Yu, M. Kanezashi, H. Nagasawa, N. Moriyama, T. Tsuru and K. Ito, Enhanced $\mathrm{CO}_{2}$ separation performance for tertiary amine-silica membranes via thermally induced

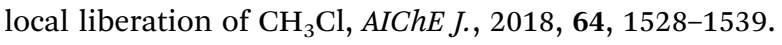

15 X. Ren, M. Kanezashi, H. Nagasawa and T. Tsuru, Plasmaassisted multi-layered coating towards improved gas permeation properties for organosilica membranes, $R S C$ Adv., 2015, 5, 59837-59844.

16 G. Gong, H. Nagasawa, M. Kanezashi and T. Tsuru, Reverse osmosis performance of layered-hybrid membranes consisting of an organosilica separation layer on polymer supports, J. Membr. Sci., 2015, 494, 104-112.

17 T. Tsuru, Silica-Based Membranes with Molecular-NetSieving Properties: Development and Applications, J. Chem. Eng. Jpn., 2018, 51, 713-725.

18 M. Elimelech and W. A. Phillip, The future of seawater desalination: energy, technology, and the environment, Science, 2011, 333, 712-717.

19 M. Nomura, T. Kodaira, A. Ikeda, Y. Naka, H. Nishijima, S.-i. Imabayashi, S.-i. Sawada, T. Yamaki, N. Tanaka and S. Kubo, Development of ion-exchange membranes for the membrane bunsen reaction in thermochemical hydrogen production by iodine-sulfur process, J. Chem. Eng. Jpn., 2018, 51, 726-731.

20 O. Myagmarjav, J. Iwatsuki, N. Tanaka, H. Noguchi, Y. Kamiji, I. Ioka, S. Kubo, M. Nomura, T. Yamaki and S. Sawada, Research and development on membrane IS process for hydrogen production using solar heat, Int. J. Hydrogen Energy, 2019, 44, 19141-19152.

21 O. Myagmarjav, N. Tanaka, M. Nomura and S. Kubo, Module design of silica membrane reactor for hydrogen production via thermochemical IS process, Int. J. Hydrogen Energy, 2019, 44, 10207-10217.

22 N. Tanaka, H. Noguchi, Y. Kamiji, H. Takegami and S. Kubo, Hydriodic iodide and iodine permeation characteristics of fluoropolymers as a lining material, Int. J. Hydrogen Energy, 2020, 45, 17557-17561.

23 B. Bhushan, N. Goswami, S. Parida, B. Rath, S. A. Kumar, V. Karki, R. Bindal and S. Kar, Corrosion behavior analyses of metallic membranes in hydrogen iodide environment for iodine-sulfur thermochemical cycle of hydrogen production, Int. J. Hydrogen Energy, 2018, 43, 10869-10877.

24 B. Huang, Y. Zhu, Y. He, S. Xu, Y. Zhang and Z. Wang, Influence of catalyst coated membranes on electrochemical bunsen reaction in the sulfur-iodine cycle, Int. J. Hydrogen Energy, 2019, 44, 9735-9742.

25 C. Forsberg, L. Trowbridge, B. Bischoff and L. K. Mansur, Sulfur thermochemical processes with inorganic membranes to produce hydrogen, Citeseer, AIChE Spring National Meeting New Orleans, Louisiana, USA, 2004.

26 G. He, R. H. Elder, D. C. Sinclair and R. W. K. Allen, High temperature oxygen separation for the sulphur family of thermochemical cycles - Part II: sulphur poisoning and membrane performance recovery, Int. J. Hydrogen Energy, 2013, 38, 785-794.

27 O. Myagmarjav, N. Tanaka, M. Nomura and S. Kubo, Comparison of experimental and simulation results on catalytic HI decomposition in a silica-based ceramic membrane reactor, Int. J. Hydrogen Energy, 2019, 44, 30832-30839. 
28 L. Meng, M. Kanezashi, X. Yu and T. Tsuru, Enhanced decomposition of sulfur trioxide in the water-splitting iodine-sulfur process via a catalytic membrane reactor, $J$. Mater. Chem. A, 2016, 4, 15316-15319.

29 M. Elma, C. Yacou, J. C. Diniz da Costa and D. K. Wang, Performance and long term stability of mesoporous silica membranes for desalination, Membranes, 2013, 3, 136-150.

30 G. Caputo, C. Felici, P. Tarquini, A. Giaconia and S. Sau, Membrane distillation of $\mathrm{HI} / \mathrm{H}_{2} \mathrm{OHI} / \mathrm{H}_{2} \mathrm{O}$ and $\mathrm{H}_{2} \mathrm{SO}_{4} /$ $\mathrm{H}_{2} \mathrm{OH}_{2} \mathrm{SO}_{4} / \mathrm{H}_{2} \mathrm{O}$ mixtures for the sulfur-iodine thermochemical process, Int. J. Hydrogen Energy, 2007, 32, 4736-4743.

31 H. Schoeman, H. M. Krieg, A. J. Kruger, A. Chromik, K. Krajinovic and J. Kerres, $\mathrm{H}_{2} \mathrm{SO}_{4}$ stability of PBI-blend membranes for $\mathrm{SO}_{2}$ electrolysis, Int. J. Hydrogen Energy, 2012, 37, 603-614.

32 M. Kanezashi, K. Yada, T. Yoshioka and T. Tsuru, Design of silica networks for development of highly permeable hydrogen separation membranes with hydrothermal stability, J. Am. Chem. Soc., 2009, 131, 414-415.

$33 \mathrm{X}$. Yu, H. Nagasawa, M. Kanezashi and T. Tsuru, Improved thermal and oxidation stability of bis(triethoxysilyl)ethane (BTESE)-derived membranes, and their gas-permeation properties, J. Mater. Chem. A, 2018, 6, 23378-23387.

34 H. L. Castricum, A. Sah, R. Kreiter, D. H. A. Blank, J. F. Vente and J. E. Ten Elshof, Hydrothermally stable molecular separation membranes from organically linked silica, $J$. Mater. Chem., 2008, 18, 2150-2158.

35 W. Puthai, M. Kanezashi, H. Nagasawa, K. Wakamura, $\mathrm{H}$. Ohnishi and T. Tsuru, Effect of firing temperature on the water permeability of $\mathrm{SiO}_{2}-\mathrm{ZrO}_{2}$ membranes for nanofiltration, J. Membr. Sci., 2016, 497, 348-356.

36 J. Zhang, R. Zhang, X. Chen, M. Tong, W. Kang, S. Guo, Y. Zhou and J. Lu, Simultaneous Removal of $\mathrm{NO}$ and $\mathrm{SO}_{2}$ from Flue Gas by Ozone Oxidation and $\mathrm{NaOH}$ Absorption, Ind. Eng. Chem. Res., 2014, 53, 6450-6456.

37 L. Meng, M. Kanezashi, J. Wang and T. Tsuru, Permeation properties of BTESE-TEOS organosilica membranes and application to $\mathrm{O}_{2} / \mathrm{SO}_{2}$ gas separation, J. Membr. Sci., 2015, 496, 211-218.

38 A. Nadar, A. M. Banerjee, M. Pai, R. Pai, S. S. Meena, R. Tewari and A. Tripathi, Catalytic properties of dispersed iron oxides $\mathrm{Fe}_{2} \mathrm{O}_{3} / \mathrm{MO}_{2}(\mathrm{M}=\mathrm{Zr}$, Ce, Ti and $\mathrm{Si})$ for sulfuric acid decomposition reaction: role of support, Int. J. Hydrogen Energy, 2018, 43, 37-52.

39 M. Landau, S. Varkey, M. Herskowitz, O. Regev, S. Pevzner, T. Sen and Z. Luz, Wetting stability of Si-MCM-41 mesoporous material in neutral, acidic and basic aqueous solutions, Microporous Mesoporous Mater., 1999, 33, 149-163.

40 H. Nayebzadeh, N. Saghatoleslami and M. Tabasizadeh, Application of microwave irradiation for fabrication of sulfated $\mathrm{ZrO}_{2}-\mathrm{Al}_{2} \mathrm{O}_{3}$ nanocomposite via combustion method for esterification reaction: process condition evaluation, J. Nanostruct. Chem., 2019, 9, 141-152.

41 M. Testa, V. La Parola, F. Mesrar, F. Ouanji, M. Kacimi, M. Ziyad and L. Liotta, Use of Zirconium PhosphateSulphate as Acid Catalyst for Synthesis of Glycerol-Based Fuel Additives, Catalysts, 2019, 9, 148.

42 P. Graf, D. De Vlieger, B. Mojet and L. Lefferts, New insights in reactivity of hydroxyl groups in water gas shift reaction on Pt/ZrO ${ }_{2}$, J. Catal., 2009, 262, 181-187.

43 T. Ishikawa, Y. Kohtoku, K. Kumagawa, T. Yamamura and T. Nagasawa, High-strength alkali-resistant sintered SiC fibre stable to $2,200{ }^{\circ} \mathrm{C}$, Nature, 1998, 391, 773-775.

44 S. Tomar, S. Gangwar, K. Kondamudi and S. Upadhyayula, $\mathrm{SO}_{3}$ decomposition over $\beta$-SiC and $\mathrm{SiO}_{2}$ supported $\mathrm{CuFe}_{2} \mathrm{O}_{4}$ : a stability and kinetic study, Int. J. Hydrogen Energy, 2020, 45, 21287-21296.

45 H. A. Khan, P. Natarajan and K.-D. Jung, Stabilization of Pt at the inner wall of hollow spherical $\mathrm{SiO}_{2}$ generated from $\mathrm{Pt} /$ hollow spherical SiC for sulfuric acid decomposition, Appl. Catal., B, 2018, 231, 151-160.

46 T. Yoshioka, M. Kanezashi and T. Tsuru, Micropore size estimation on gas separation membranes: a study in experimental and molecular dynamics, AIChE J., 2013, 59, 2179-2194. 